\title{
Scattered Light in a Flood-plain Lake of Central Amazônia ${ }^{(1)}$
}

\author{
W. L. B. BRINKMANN \\ Instituto Nacional de Pesquisas \\ da Amazônia
}

\begin{abstract}
The light intensity below the surface of Lago Castanho was recorded at 10 minute intervals and compared to the total light intensity above the water surface. Scattered light of the lake water was rather constant and it was found to be sufficiently high to support the growth of photoautotrophic organisms in the near-surface layer. Below the floating plant communities scattered light was extremely low in intensity.
\end{abstract}

\section{INTRODUCTION}

Actually, the light falling upon the surface of the lake or the floating-leaf plant communities is composed of direct sunlight and/or scattered sunlight. Sunlight, however, is essential for photosynthesis and heat in the aquatic environment.

Pure water absorbs light selectively. Light absorption is negligible between $4000 \mathrm{~A}$ and $5800 \mathrm{~A}$ in the visible part of the electromagnetic spectrum.

Absorption is strong in the ultraviolet, increases in the orange and red region of the spectrum and rises steeply in the near infrared.

Pure water does not exist in nature. Consequently, the penetration of light into natural water is determined mainly by dissolved substances, suspended materials, organisms and some other important factors as the angle of incident light, season and latitude.

\section{MATERIAL AND METHODS}

The lake under study, the Lago do Castanho, is a flood-plain lake of the River Solimões, approximately $80 \mathrm{~km}$ upstream of the Rio Solimões and Rio Negro confluence (fig. 1).
On May 29th and 30th, 1969, total light at the lake surface and scattered light directed upward from the water (sometimes referred to as the "light of the water" - Hutchinson, 1957) was measured in 10-minute intervals namely 1) total light received at the lake surface, 2) scattered light of the lake water and 3) scattered light of the lake water below dense communities of floating-leaf plants.

The total light, i. e. the direct light and/or scattered sunlight received at the surface of the lake was recorded by a face-up exposed selenium photecell mounted on a tripod at about one meter above the lake surface. The photocell was connected with a Standard Luxmeter II of the B. Lange, Berlin type. The photocell is sentive for light at $3800 \mathrm{~A}$ to $6800 \mathrm{~A}$ of the electromagnetic spectrum, having a transmissivity peak at $5000 \mathrm{~A}$ to $6000 \mathrm{~A}$.

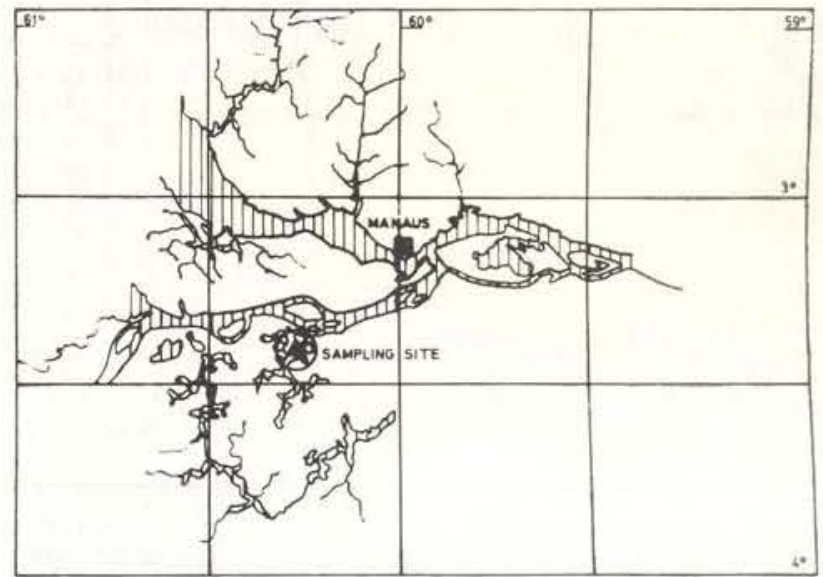

Figure 1 - Sampling site at Lago do Castanho - Central Amazonia .

(1) - Granted by the Banco Nacional de Desenvolvimento Econômico (contract INPA/FUNTEC, 89/70), and by the Conselho Nacional de Pesquisas. 
The total light received at the surface of the lake was related to 1) full direct sunlight, 2) direct sunlight and scattered sunlight and 3 ) indirect sunlight (sun behind clouds) (fig. 2).

The overcast was estimated in fractions of one tenth while the instantanuous wind velocity was measured coincidently with ligh intensity readings approximately one meter above the lake surface (fig. 2).

The scattered light of the lake water was measured by a face-down exposed photoceli cautiously set up at about $2 \mathrm{~cm}$ depth of water at a distance of 10 meters from the open lake surface. The floating-leaf plants were of the Paspalum repens and Echinochloa polystacha communities. Both species contribute primarily to the floating islands drifting down the Amazon (Junk, 1970). Actually, these plant

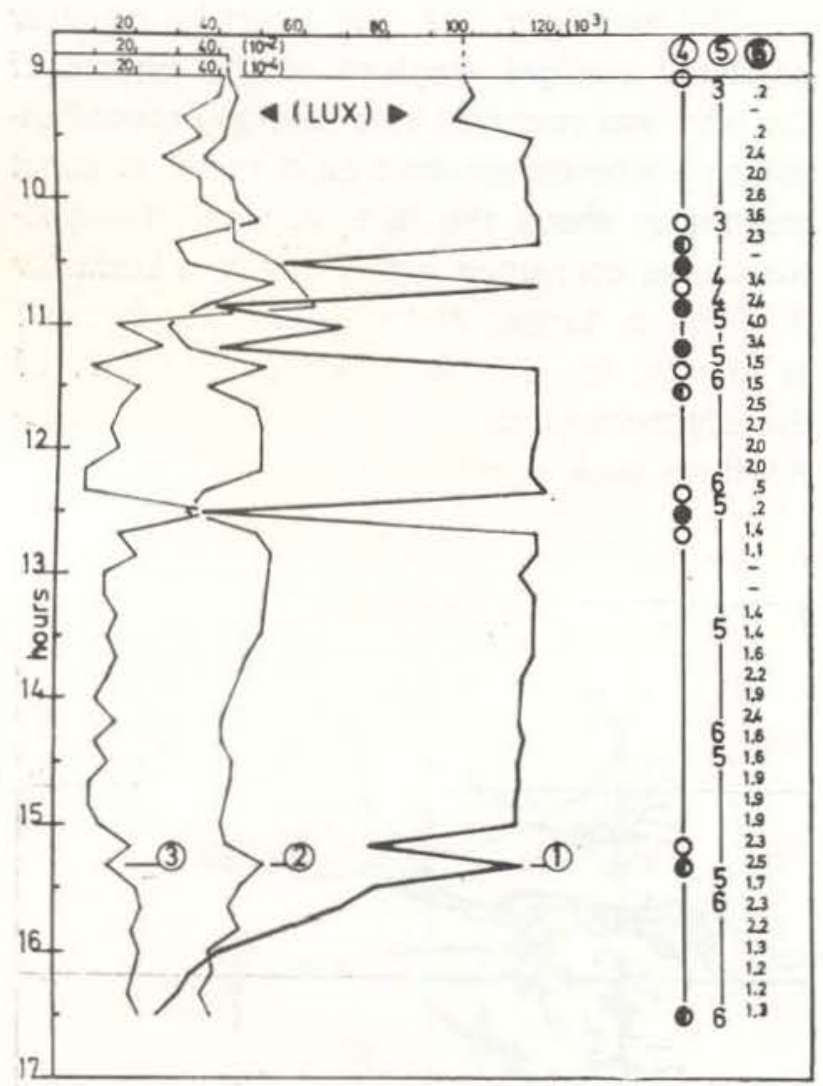

Figure 2 - Diurnal variation of (1) total light intensity received at the surface of the lake, (2) scattered light intensity of the lake water, (3) scattered light intensity of the lake water below floating vegetation ( 2 and 3 measured light/total light in \%), (4) sunlight, ( 0 ) direct sunligth, ( $\left.{ }^{\circ}\right)$ direct and scattered sunlight. (-) indirect sunlight, (5) overcast $(n / 10)$, and (6) instantanuous wind velocity $(\mathrm{m} / \mathrm{sec})$ on Lago do Castanho - Central Amazonia (May 30th, 1969). communities are very common in those floodplain lakes of the River Solimões, that show up with the great seasonal fluctuations of the water level.

\section{RESULTS AND DISCUSSION}

The total sunlight referred to as full direct sunlight oscillated at about 100.000 on May $30 \mathrm{th}$, between $0900 \mathrm{~h}$ and $1530 \mathrm{~h}$ (fig. 2) When the sun was free of clouds ieither an overcast up to seven tenths, nor hazy conditions interfered significantly with this light intensity level. With the sun behind clouds, however, total light intensity received at the surface of the lake was heavily reduced (down to about 30.000 Lux). The normal curve of daily light intensity forms two steep slopes in the morning (between $0600 \mathrm{~h}$ and $0730 \mathrm{~h}$ ) and the afternoon (between $1700 \mathrm{~h}$ and $1800 \mathrm{~h}$ ) and a plateau-like pattern during daytime as far as full sunlight conditions are concerned. Rapid decrease in light intensity occurs, when clouds cover the sun.

The scattered light intensity in the water of the lake ranged from 102 Lux to 670 Lux. The average light intensity in the period of measurements was 500 Lux, as to full sunlight conditions. This average decreased to 200 Lux when the sun was behind clouds The intensity of scattered light of the lake water was in the order of 0.5 per cent of the total incident light received at the lake surface. This intensity level was nearly constant during daytime and was not influenced by wind below a velocity of 4 meter/second.

The submerged photocell received the light of the water from points at various depths and distances of the waterbody below. As the upward scattered light of the lake water depends on the intensity and the angle of incidence of the total light received at the lake surface, the low intensity of the light of the water of Lago do Castanho with less thant 1 per cent is quite obvious. Futheron, light passing through the column of lake water undergoes quenching, widely controlled by suspended materials. During the flood-season the Lago do Castanho and the River Solimões are connected by channels. According to Sioli (1967) the 
suspension load in the Solimões water ranged from $50 \mathrm{mg} / 1$ to $150 \mathrm{mg} / 1$ dependent on season. The Secchi disk transparency was in the order of $25 \mathrm{~cm}$ to $40 \mathrm{~cm}$, respectively. During the flood-season of the River Solimões in 1971, the suspended materials in the Lago do Castanho water ranged from $20 \mathrm{mg} / 1$ to $120 \mathrm{mg} / 1$ (verbal communication: Dipl. geol. H. Köhle).

In June, 1968 the development of bacteria and algae in Lago do Castanho waters showed a maximum at about $50 \mathrm{~cm}$ depth (Schmidt, 1969). The Secchi disk transparency was at about 2 meter depth. The same author reported on a transparency of about $80 \mathrm{~cm}$ in April 1968.

While the suspension load of the Lago do Castanho water depends qualitatively and quantitatively on the flood water level of the River Solimões as principle source of new suspended material, the development of phytoplankton and zooplankton depends widely on the "law of the minimum", as far as nutrients are concerned, and on the "law of tolerance" with respect to environmental controls.

The scattered light intensity (range: 102 Lux) in the period of measurements is sufficiently high for a further support of the de. velopment of photoautotrophic organisms in the near-surface water layer during high water level in the Lago do Castanho (flood-season of the River Solimões).

But the rain season, which occurs coincidently, records a considerable number of days with worse light conditions, i.e. light may be one of the limiting factors for the development of photoautotrophic organisms. Incidently, shanges in the concentration of suspended solids in the lake water, as shown above, will, in addition, alter the amount of available light.

The scattered light intensity of the Lago dn Castanho water below the Paspalum repens and Echinochloa polystacha communities was extremely low (fig. 2). In the period of measurements the observed intensity maximum was 20 Lux. Often, the light intensity was below detection limit.

The sunlight received by the floating vegetation is multiple scattered when passing through the population above water surface. Even under full sunlight conditions primarily scattered light will reach the air/water inter face. The highest efficiency of light penetration will occur, when full direct sunlight and no wind are recorded. The relative light intensity of the light of the lake water below floating-leaf plants peaked with the sun behind clouds and low wind velocity. The maximum was calculated with 0.03 per cent of the total incident light.

Paspalum repens and Echinochloa polystacha communities develop a very dense root system, where incoming light will be multiple scattered again. Light absorption and scattering reduce the penetrating light to an unsig. nificant minimum. According to Junk (1970) large quantities of seeds were filtered by the extensi. ve root systems. Rather no germination occured. The lack of light of specific wavelengths might be one of the reasons. On the other hand, an accumulative heat effect was observed. According to Junk (1970) temperatures above $40^{\circ} \mathrm{C}$ were recorded. High temperature, nearly black-out conditions and the lack of water circulation are some of the controlling factors below the floating-leaf plant communities. although the effect of the controls will change with the different states of development of the floating-leaf plant populations.

\section{CONCLUSIONS}

Scattered light of the lake water in the period of measurements (average under full sunlight conditions: 500 Lux) was sufficiently high for support of the development of photoautotrophic organims in the near-surface layer But during the rain season (November - May) a considerable number of days has worse light conditions. There is some evidence, that light is one of the environmental controls as far as the development of photoautotrophic organisms is concerned.

Scattered light of the lake water below the floating plant communities was extremely low. Light is a significant control for the de. velopment of photoautotrophic organisms in the root-zone of the floating vegetation. 


\section{ACKNOWLEDGEMENT}

The author is endebted to the Max Planck institute of Limnology, Departament for Tropical Ecology, Plön for supplying him with the facilities necessary for these investigations in Central Amazonia.

\section{RESUMO}

Foram medidas, cada 10 minutos, a luz total incidindo sobre a superfície do Lago do Castanho e a luz difusa abaixo da superfície do lago. Verificou-se, nas camadas superficiais da água do lago, intensidade luminosa suficiente para assegurar o desenvolvimento de organismos foto-autotróficos, com variaçóes mínimas durante o dia. Embaixo das massas de capim flutuante, a intensidade da luz difusa era extremamente baixa, máximo: $20 \mathrm{Lux}$.

\section{LITERATURE CITED}

Hutchinson, G. E.

1957 - A treatise on Limnology. New York, John Wiley \& Sons. v. I.

JUNK, W.

1970 - Investigations on the Ecology and Production. Biology of the "Floating Meadows" (PaspaloEchinochloctum) on the middle Amazon. Part I. The floating vegetation and its ecology. Amazoniana, Kiel, 2(4) : 449-495.

¿CHMIDT, G. W.

1969 - Vertical distribution of Bacteria and Algae in a tropical lake. Int. Revue ges. Hydrobiol. 54(5): 791-797.

SroLI, $\mathrm{H}$.

1967 - Studies in Amazonian water. Atas Simp, sôbre a Biota Amazônica, 3 (Limnologia) : 9-50. 